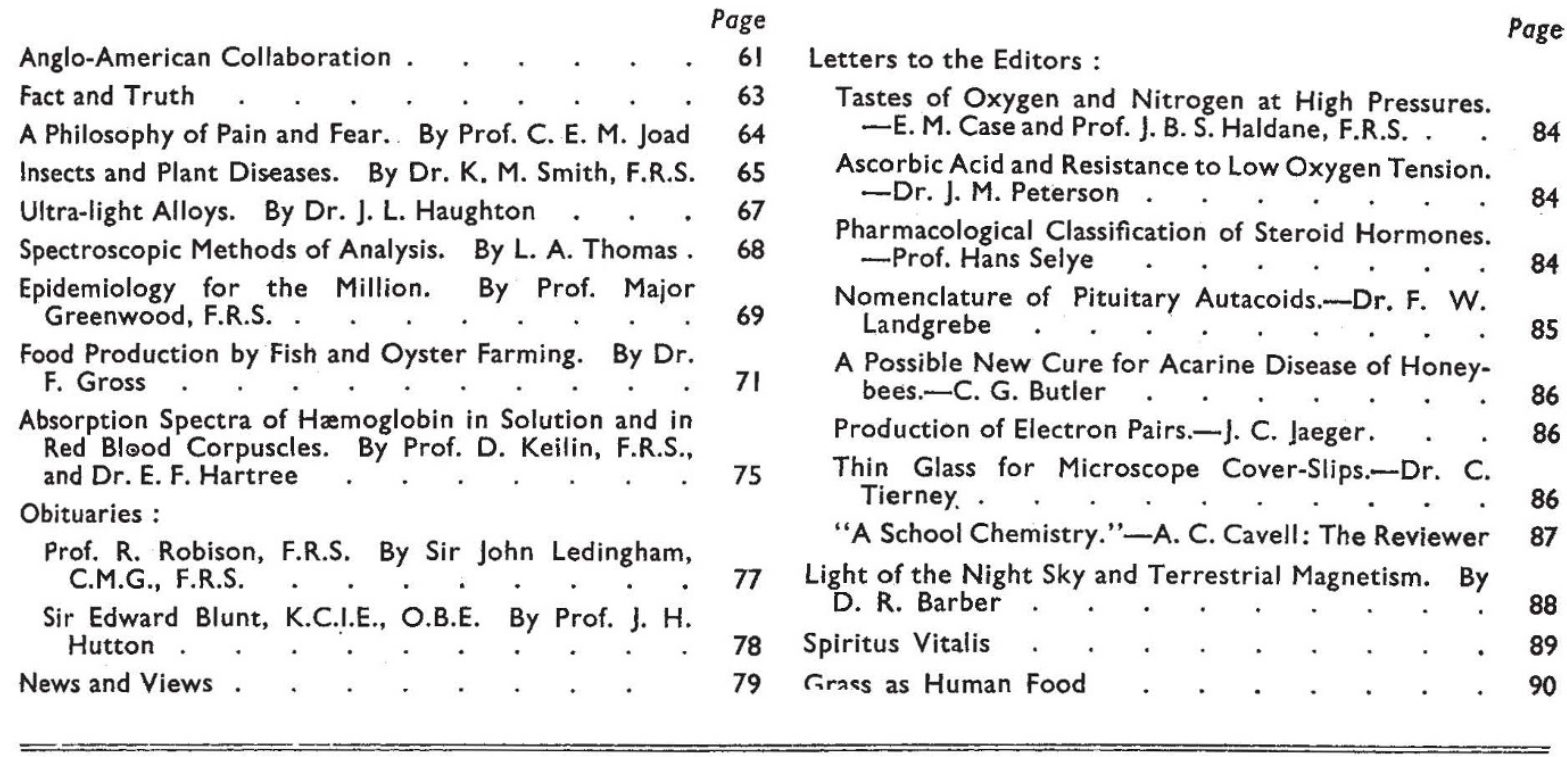

\title{
ANGLO-AMERICAN COLLABORATION
}

TN a speech read on his behalf on December 11, Lord Lothian affirmed his belief that the only nucleus round which a stable, peaceful, democratic world could be built after this War was the possession by the United States and Great Britain of airpower, sea-power and key positions superior to those of any possible totalitarian rival. Peace and order always depend on the existence of an overwhelming power behind just law, and more and more people have come to the conclusion that all real hope depends on some form of co-operation between the United States and the British Commonwealth of Nations.

Without some such general realization and indeed actual co-operation, it is almost inconceivable that the British Ambassador in Washington could address the people of the United States so directly, however careful he might be, like Lord Lothian, to state the essential facts and to emphasize the responsibility of his hearers to decide for themselves. The events of the last six months have abundantly justified such frankness and demonstrated the recognition by the two peoples of their common danger and their solidarity in defence of the ideals and heritage which they share. AngloAmerican co-operation has become a reality and a dominant factor in the war itself and in the peace and reconstruction to follow. The questions at issue are now those of the extent and form which such co-operation will take.

With the growing scale of America's contribution in the material sphere, there has been a notable contribution in the moral sphere. It is no disparagement of the speeches of $\mathrm{Mr}$. Churchill, of Lord Halifax or of Mr. Eden to say that the major contributions in the statement of the moral issues of the War and its social, economic and spiritual objectives have latterly come from the American side. That might well be expected, but the warmth and sincerity with which they have been welcomed indicates how fully they are shared in Great Britain and how wide and firm is the foundation upon which practical measures of co-operation can be based.

Nor should it be imagined that this affinity of ideals and purpose is limited to leaders. The American Press affords decisive evidence that President Roosevelt, Mr. J. G. Winant and Mr. Wilkie are speaking for, as well as to, their countrymen. American periodicals such as Fortune leave their readers in no doubt as to the consequences which flow from the Lease-Lend Act. The probability of a direct collision with Germany is recognized, as well as the opportunity which the acceptance of that challenge would afford the United States to make the international view effective. The decision to fight for international 
democracy would indeed not only be a decision to fight for a world in which there was still room for American ideals. It would also be the opportunity to build a new era in which the dualism which has hitherto characterized American foreign relations could be transcended.

Mr. Streit's new book "Union Now with Britain"* bears striking testimony to the startling transformation of American opinion and policy from the consistently isolationist attitude which characterized it during $1919-39$. Written as it is primarily and essentially for Americans, it is this changed outlook, sensed or implied rather than directly described, which is the most striking feature of the book in contrast with "Union Now", overshadowing the fact that the intervening two years have witnessed the passage, one by one, under the Nazi heel, of eight of the fifteen democracies for the federation of which he pleaded in "Union Now". The successive fall of these democracies before the same tactics, has brought home to the United States not merely the fuller realization of the ideals and trust for safeguarding man's heritage of freedom which she shares with Great Britain, but also the clear understanding that the choice for her also is between standing now by Britain's side or fighting later and alone in a totalitarian world.

Ostensibly Mr. Streit's new book is concerned with the organization of co-operation, with the development of the most effective machinery for harnessing the resources of the United States and the six democracies of the British Empire to their common task. Fundamentally the book is vibrant with the moral conviction and ideals which have given such force to President Roosevelt's and Mr. J. G. Winant's speeches. The spirit and conviction on which his views are based are irresistible. No nation can live to itself alone. Each nation must give, and he calls on Americans to give fully and with open hands the best they have.

It is on this basis that Mr. Streit pleads for a union of the United States with the six democracies of the British Empire-the United Kingdom, Australia, Canada, Eire, New Zealand and the Union of South Africa- on the lines of the American federal system but with modifications which introduce something of the British parliamentary and Cabinet systems, and starting with a limited union. The working out of a broader and permanent union would be left until.later, but the provisional union is intended and planned to be the nucleus of a world federal union to which each western European democracy would be admitted as soon as it is no longer occupied by the forces of dictatorship. Beyond that, the admission of such peoples as the Germans themselves is contemplated

* Union Now with Britain. By Clarence K. Streit. Pp. 286. (London: Jonathan Cape, Ltd., 1941.) 7s. 6d. net. when, by ending autocracy at home, they have proved their devotion to democratic principles and their capacity to practise them.

Mr. Streit writes persuasively of the capacity of such a union to win the war as well as to win the peace. From the outset the Union would be prepared to negotiate armistice and peace terms with any Government àttacking any territory of the Union on conditions of no indemnities, no reparations, occupations or annexations, and of arbitration of disputes on details. Such an announcement could be used to undermine the totalitarian regimes, encourage revolt and distrust among them and promote the downfall of dictatorship.

Writing eagerly with the moving quality of vivid talk, Mr. Streit rapidly outlines a union programme and discusses alternatives to such a policy. For what he has to say of Anglo-American co-operation there can only be the most cordial assent, and the basic proposal of the creation of a community of principles is inescapable. It is indeed implicit in such speeches as those of Mr. J. G. Winant's to the English-Speaking Union, with its insistence that the common ideals of the English-speaking peoples of this world are not ideals from which other peoples are excluded, on the drawing together of the English-speaking peoples in a struggle to preserve not cnly their common heritage but also the common ideals of civilized men everywhere, and its firm declaration that this is not Britain's fight alone. The ultimate stakes, the four freedoms of which President Roosevelt has spoken, are the foundation of their common effort, and that the time of action, the hour of decision, has arrived for all who love freedom can no longer be denied.

While the gap between political realities and the vision of Mr. Streit's "Union Now" has been greatly narrowed in the last two years, his argument is less conclusive as to the form which the organization of co-operation should take. It may be possible to demonstrate that had the union existed, the democracies included in Mr. Streit's earlier union would not have fallen. There is, however, no evidence that, even if made earlier and accepted, the offer of union which Great Britain made to France would have averted the fall of France. Federal union alone between Great Britain and France could scarcely have eliminated in time those weaknesses which led to the fall of France, though it might have ensured that the French fleet and French colonies continued the struggle.

On the other hand, as Fortune points out, the Lend-Lease Act really constitutes the first crude step in union. By its terms Great Britain and the United States pool such matters as military equipment, production, specification and design, hitherto strictly national. Moreover, the same pool is 
offered and made available to any other country that will take the side of democracy by standing up against Germany. This has been done, however, on the basis of friendship and engagement in a common venture, and that of itself may suggest that, as alternative to federal union, the British Commonwealth of Nations, united by common conventions and understandings about the position and the action of its members, not by virtue of common federal institutions, at least deserves consideration.

It is a mistake to insist too crudely that the choice is between federal union or a formal alliance, as Mr. Streit does, and to reject the latter as bad. It is at least possible that there is a third way, tentative and difficult, but in the end surer and wiser - the experimental way of finding and working out our common understandings and forging the appropriate instruments to serve common purposes. Already we have seen the chastening of nationalism in the British Commonwealth. Given the dynamic outlook and readiness to face change and try new methods, the consciousness of common ideals and traditions which lend Mr. Streit his own inspiration, the same spirit which has worked out effectively the relations between the United Kingdom and the
Dominions may work no less harmoniously and effectively between the United States and the British Empire.

To that task must be addressed not idealism alone but also the dispassionate spirit of scientific inquiry, ever advancing step by step as new experiments in co-operation are tried. To such experiments the moral appeal and the rapidly developing world situation give urgency, but it is only on the basis of ascertained facts that Great Britain and the United States can discharge adequately their inescapable responsibilities in peace or in war for the defence of freedom and their common heritage. Whether the first or final stage be union, partnership in some more or less organized form will be required to resolve the conflict between nationalism and trade, industry and culture, and make possible a reconstruction of the world on principles which transcend the national sovereignty that has plunged it into chaos. In such a partnership Great Britain and the United States may well once more attest the truth of Lowell's prophetic words of February 1861, and their manhood make a greater opportunity out of the great danger which they at present share.

\section{FACT AND TRUTH}

$\mathrm{F}$ ROM time to time there flare up echoes of the old controversy between science and religion; not, be it noted in any official form in the sense that leaders of either party take part, but individuals of deep convictions suddenly produce attacks, occasionally in print, which one had hoped were disposed of half a century ago. The fact that such attacks still occur is a reflection on men of science themselves, indicating that they have not yet succeeded in spreading the message of seience so widely as they should have done; though it may be in part due to singular obtuseness on the part of their hearers.

The ill-informed have in recent months frequently blamed science for the misuse that has been made of its gifts to mankind, for the developments of the means of waging modern warfare. With that aspect we have often dealt, and we need not go over the ground again. A particularly subtle form of attack on science, however, is to take the line that the facts of science actually have the impermanence of matter, which changes and fades continually, and to contrast them with the truths of religion, which are permanent. Science being based on facts, and the facts relating to it mainly on matter, the argument is, on the face of it, worth examination.
The Oxford Dictionary gives a long definition of fact_-"thing assumed as basis for inference"; "thing certainly known to have occurred or be true". True is defined there as "in accordance with fact". How do these definitions fit in with the outlook of the man of science?

There can be surely no question that the now vast body of scientific workers regard their observations as facts, and also they have a high moral sense of obligation for their pronouncements. As the result of carefully devised experiment, results are obtained which become a basis for inference. These are published for criticism by fellow workers, and if no flaws or omissions are found in the experimental work, they are accepted as facts and form the basis of theories--even of rival theories, a choice between which is only possible when further facts are available. Theories must be altered to fit facts ; facts can never be adjusted to fit theories.

In more leisurely days, when a research was published after completion of the work, both facts and theories had been frequently tested during a year or more of investigation, and the final conclusions had a high degree of permanence. When work, however, such as that carried out in the Cavendish Labóratory, is of the greatest inter. national interest, it is desirable to make the 